\title{
RATIONALIZE MAIZE IRRIGATION WATER USING MODERN IRRIGATION SYSTEMS AND PLASTIC MULCHING IN CLAYEY SOILS OF FAYOUM
}

\author{
Tolba S. Abdel-Aal*, Abd El-Aty M. Ibrahim*, Mohamed A. Abdel-Razek* and
}

Eman G. M. Abd-Allah.

*Soils and Water Department, Faculty of Agriculture, Fayoum University, ;;;; ABSTRACT

Using the modern irrigation systems lead to water lost decrease, controlling the quantity and increase crop productivity. The current study aims to evaluate the surface, improved surface and drip irrigation systems to rationalize maize irrigation water in soils. Field experiments were conducted in Sanores District, Fayoum Governorate. The treatments include three irrigation systems (surface, improved surface and drip), three deficit irrigation treatments (100\%, $80 \%$ and $60 \%$ of ETc) and three soil plastic mulching treatments (without, white plastic and black plastic). All treatments were combined in the complete randomized blocks design (spilt -spilt plot) with three replicates. Maize (Zea mays $L$, variety 321 ) was planted during two summer seasons (2017 and 2018). Class A Pan was used for estimating the daily ETo values to determine the intervals between irrigation treatments. Disturbed and undisturbed soil samples were collected from the experimental field before conducting such treatments. Measurements of maize growth parameters and yield were carried. Some crop water relations of maize were determined. Statistical analysis for the obtained data was performed.

Results indicated that the highest values of plant height, cobs No. per plant, cob weight, number of rows per cob, weight of 100 grains and grains yield of maize were coincided with improved surface irrigation system, irrigation treatment $(80 \%$ of ETc) and black plastic mulching. Also, the highest value of forage weight of maize was recorded with surface irrigation system, irrigation treatment $(100 \%$ of ETc) and soil black plastic mulching. The mean values of the water consumptive use of maize plants were significantly decreased by 31.26 and $12.10 \%$ under drip irrigation compared with surface and improved surface irrigation systems. The mean values of water productivity of maize crop significantly increased by 27.13 and $3.88 \%$ under drip irrigation compared with surface and improved surface irrigation systems, respectively. It could be concluded that improved surface irrigation system, irrigation treatment ( $80 \%$ of ETc) and black plastic mulching saved about $20 \%$ of the applied irrigation water (about $965 \mathrm{~m}^{3} \mathrm{ha}^{-1}$ ), as well as, the highest grains yield of maize plants in clayey soils under Fayoum conditions.

Keywords: Water rationalization, improved surface irrigation, drip irrigation, deficit INTRODUCTION irrigation, soil mulching, maize yield and water productivity.

Agriculture consumes approximately $70 \%$ of the available fresh water on the Earth. Maize considered as one of the main cereal crops occupying the second order after wheat in Egypt. The total cultivated area of maize reached about 2.47 million fed. in 2015 and maize grain production in Egypt is approximately 8.059 million ton (FAO, 2016). The efficient use and rationalization of the Egyptian irrigation water

Fayoum J. Agric. Res. \& Dev., Vol. 34, No.1, January, 2020 
in agriculture is need to reduce the cultivation of crops with high water consumption, gradually replace crops consuming less water, and installing developed irrigation systems in the old land to maximize the use of the irrigation water (Ahmed et al., 2013).

Gated pipes irrigation gave a water saving $25-28 \%$ of water use efficiency compare to conventional basin irrigation system (Jibin and Faroud, 2007). Abo Soliman et al., (2008) concluded that the lowest amount of water applied, consumptive use, water losses, and the highest values of water use efficiency and water application efficiency were obtained under gated pipes. Sonbol et al. (2010), Abdel-Raheem and Elwan (2016) recommended the application of gated pipes under different soil texture and weather conditions in Egypt.

Under drip irrigation system the mean grain yield of maize increased with increasing water use which resulted in $2.67,3.62,3.89$, and $4.7 \mathrm{t} \mathrm{ha}^{-1}$ grain yield at 60, 40, 20 and 0\% irrigation water deficits treatments, respectively (Silungwe et al., 2010 and Kadasiddappa et al., 2016). Drip irrigation method was found significantly superior than surface furrow irrigation in terms of growth parameters of maize (Ramulu et al., 2019).

Wang et al. (2011) reported that the using of plastic sheet was capable of promoting deep soil water, improving crop growth, accelerating the soil-plantatmosphere transport and significantly improve crop water use efficiency. Abd ElWahed and Ali (2013) reported that soil mulching credited to increase water contents in soil due to reduce evaporation. Memon et al. (2018) reported that the saving percentages of water were $52.22 \%$ and $31.00 \%$ at plastic mulch and without mulching, respectively compared with traditional irrigation practice.

Aguilar et al. (2007) found that limited or regulated deficit irrigation is one way of maximizing productivity of total applied water (PAW); thus, the limited irrigation treatment reached a higher PAW value $\left(2.66 \mathrm{~kg} \mathrm{~m}^{-3}\right)$ than full irrigation $\left(1.90 \mathrm{~kg} \mathrm{~m}^{-3}\right)$. Shinde et al. (2009) showed that irrigation scheduled at $0.80 \mathrm{IW} / \mathrm{CPE}$ ratio recorded significantly higher plant height and dry matter of maize.

This study aims to rationalize the irrigation water of maize plants grown in clayey soils using improved surface and drip irrigation systems and soil plastic mulching under Fayoum conditions.

\section{Materials and methods}

Field experiment was conducted in Sanores District, Fayoum Governorate, Egypt, as a clayey texture soil during two summer seasons of 2017 and 2018. The main initial soil physical and chemical properties of the experimental soil were presented in Table (1). Three different irrigation systems represented the main plots, i.e., surface $\left(S_{1}\right)$, improved surface $\left(S_{2}\right)$ and drip $\left(S_{3}\right)$. Each main plot was divided into three deficit irrigation treatments, i.e., $100 \%\left(\mathrm{I}_{1}\right), 80 \%\left(\mathrm{I}_{2}\right)$ and $60 \%\left(\mathrm{I}_{3}\right)$ of ETc. 
RATIONALIZE MAIZE IRRIGATION WATER USING MODERN.......... 50 Tables (1). Some initial soil physical and chemical properties of the experimental soil (as average of the two seasons)*.

\begin{tabular}{|c|c|c|c|c|c|}
\hline \multirow{2}{*}{\multicolumn{2}{|c|}{ Soil physical properties }} & \multicolumn{4}{|c|}{ Depth (cm) } \\
\hline & & 0-20 & $20-40$ & $40-60$ & Mean \\
\hline \multirow{4}{*}{$\begin{array}{l}\text { Particle size } \\
\text { distribution }\end{array}$} & Sand $\%$ & 27.27 & 28.50 & 28.88 & 28.22 \\
\hline & Silt \% & 26.80 & 25.18 & 23.88 & 25.29 \\
\hline & Clay \% & 45.94 & 46.33 & 47.25 & 46.51 \\
\hline & Texture class & Clay & Clay & Clay & Clay \\
\hline \multicolumn{2}{|c|}{ Bulk density $\left(\mathrm{Mg} \mathrm{m}^{-3}\right)$} & 1.26 & 1.31 & 1.37 & 1.31 \\
\hline \multicolumn{2}{|c|}{ Particle density $\left(\mathrm{Mg} \mathrm{m}^{-3}\right)$} & 2.65 & 2.66 & 2.66 & 2.66 \\
\hline \multicolumn{2}{|c|}{ Total porosity, \% volume } & 52.96 & 50.85 & 48.50 & 50.77 \\
\hline \multicolumn{2}{|c|}{ Air porosity, \% volume } & 40.72 & 37.05 & 33.33 & 37.03 \\
\hline \multicolumn{2}{|c|}{ Void ratio (e) } & 1.13 & 1.04 & 0.95 & 1.04 \\
\hline \multicolumn{2}{|c|}{ Hydraulic conductivity $\left(\mathrm{cm} \mathrm{hr}^{-1}\right)$} & 0.24 & 0.17 & 0.13 & 0.18 \\
\hline \multirow{3}{*}{$\begin{array}{l}\text { Soil moisture } \\
\text { constants, } \% \text { at: }\end{array}$} & Field capacity & 38.83 & 37.56 & 37.00 & 37.80 \\
\hline & Wilting point & 20.31 & 21.19 & 22.20 & 21.23 \\
\hline & Available water & 18.52 & 16.37 & 14.80 & 16.56 \\
\hline \multicolumn{6}{|c|}{ Soil chemical properties } \\
\hline \multicolumn{2}{|c|}{$\mathrm{pH}(1: 2.5$ soil-water suspension) } & 7.27 & 7.44 & 7.69 & 7.47 \\
\hline \multicolumn{2}{|c|}{$\mathrm{ECe}\left(\mathrm{dS} \mathrm{m}^{-1}\right)$} & 1.22 & 1.06 & 1.46 & 1.25 \\
\hline \multirow{4}{*}{$\begin{array}{l}\text { Soluble cations } \\
\left(\mathrm{mmol}^{+} \mathrm{L}^{-1}\right)\end{array}$} & $\mathrm{Ca}^{++}$ & 3.35 & 2.85 & 4.10 & 3.43 \\
\hline & $\mathrm{Mg}^{++}$ & 2.50 & 1.95 & 3.00 & 2.48 \\
\hline & $\mathrm{Na}^{+}$ & 5.95 & 5.00 & 7.35 & 6.10 \\
\hline & $\mathrm{K}^{+}$ & 0.55 & 0.45 & 0.40 & 0.47 \\
\hline \multirow{4}{*}{$\begin{array}{l}\text { Soluble anions, } \\
\left(\mathrm{mmol}^{+} \mathrm{L}^{-1}\right)\end{array}$} & $\mathrm{CO}_{3}=$ & - & - & - & - \\
\hline & $\mathrm{HCO}_{3}^{-}$ & 2.33 & 1.48 & 3.34 & 2.38 \\
\hline & $\mathrm{Cl}^{-}$ & 7.03 & 5.50 & 7.55 & 6.69 \\
\hline & $\mathrm{SO}_{4}=$ & 3.05 & 3.55 & 3.85 & 3.48 \\
\hline \multicolumn{2}{|c|}{$\mathrm{CaCO}_{3}, \mathrm{~g} \mathrm{~kg}^{-1}$} & 55.05 & 48.50 & 21.80 & 41.78 \\
\hline \multicolumn{2}{|c|}{ Organic matter, $\mathrm{g} \mathrm{kg}^{-1}$} & 19.30 & 15.05 & 11.50 & 15.28 \\
\hline
\end{tabular}

*Each value in this table is mean of three replicates.

Each sub main plot was divided into three soil mulching, i.e., without $\left(\mathrm{M}_{0}\right)$, white plastic mulch $\left(\mathrm{M}_{1}\right)$ and black plastic mulch $\left(\mathrm{M}_{2}\right)$. All treatments combined in the complete randomized blocks design (spilt - spilt plot) with three replicates.

The crop evapotranspiration (ETc) was calculated from the following equation, according to Doorenbos and Pruitt (1992):

$$
\mathbf{E T}_{\mathbf{c}}=\mathbf{E T}_{\mathbf{o}} \times \mathbf{K}_{\mathbf{c}}
$$

ET $_{\mathbf{o}}$ is the "Reference ET" (the amount of full water used by a well irrigated) and $\mathbf{K}_{\mathbf{c}}$ is the "Crop Coefficient" (A factor that is used to convert $\mathrm{ET}_{\mathrm{o}}$ to potential ETc).

Fayoum J. Agric. Res. \& Dev., Vol. 34, No.1, January, 2020 
$\mathrm{K}_{\mathrm{c}}$ values of maize plants were $0.3,0.8,1.2$ and 0.6 at the four growth stages. Under surface and improved surface, the number of irrigations at all different irrigation treatments are presented in Table (7).

Under improved surface irrigation, PVC pipes (5 inches in diameter) were used and an orifice gated are distributed along the pipes with $3 \mathrm{~m}$ spacing. Gated pipes are connected directly with a water pump to convey and distribute the water to the head of the irrigated fields (furrows method). The discharge of tap was $100 \mathrm{~L}$ min. $^{-1}$ and the operation time varied with the application of three irrigation treatments.

Under drip irrigation system, the amounts of irrigation water applied (IWA) of each plot were determined using the following equation (Abd El-Wahed and Ali, 2013):

$$
\text { IWA }=\frac{A \times E_{\mathbf{c}} \times \mathbf{L}_{\mathbf{i}}}{\mathbf{E}_{\mathrm{a}} \times 1000}
$$

Where: $\quad$ ETc $=$ the crop evapotranspiration $\left(\mathrm{mm} \mathrm{day}^{-1}\right)$.

IWA $=$ the irrigation water application $\left(\mathrm{m}^{3}\right), \quad \mathrm{A}=$ the area $\left(\mathrm{m}^{2}\right)$.

$\mathbf{L i}=$ the irrigation intervals (day), $\quad \mathrm{E}_{\mathrm{a}}=$ the application efficiency (\%).

Under drip irrigation system, the number of working hours at all different irrigation treatments are presented in Table (7). To achieve the intervals between irrigations in surface irrigation system, scheduling crop irrigation water of maize using the daily Class A Pan evaporation values $(\mathrm{mm})$ were recorded. Monthly mean weather data for years 2017 and 2018 were obtained from Etsa meteorological station, Fayoum, Egypt. The daily $\mathrm{ET}_{\mathrm{o}}$ was computed according to (Allen et al., 1998). The soil moisture constants of the effective root zone $(0-60 \mathrm{~cm})$ were estimated (Table, 2).

All treatments were planted with maize (Zea mays $L_{\text {. }}$, variety 321 ) in two summer seasons (2017 and 2018). Maize grains were planted manually in the $6^{\text {th }}$ and $4^{\text {th }}$ August in the $1^{\text {st }}$ and $2^{\text {nd }}$ seasons, respectively, in hills $30 \mathrm{~cm}$ apart from each other, the distance between rows was $70 \mathrm{~cm}$. Harvesting of the maize plants was after 120 days from planting. Other cultural management practices for the grown maize have been conducted as the recommendations of the Egyptian Ministry of Agriculture. Measurements of maize plant parameters, yield and yield components were carried out during and after the harvesting stage of the maize plants.

Disturbed and undisturbed soil samples were collected from the experimental field at three depths $(0-20,20-40$ and $40-60 \mathrm{~cm})$ before proceeding irrigation treatments and mulching. Some initial soil physical properties were determined according to Klute (1986), also, some initial soil chemical characteristics were determined according to Page et al. (1982) Table (1).

To obtain water consumptive use, the soil moisture percentage was gravimetrically determined on day basis just before and after 48 hour of each irrigation, as well as at harvesting time. The amount of water consumed (C.U) from the root zone between each two successive irrigations as a water depth in $\mathrm{cm}$, was calculated from the following equation: (Israelsen and Hansen, 1962).

Fayoum J. Agric. Res. \& Dev., Vol. 34, No.1, January, 2020 


$$
\text { C. } \mathrm{U}\left(\mathrm{ET}_{\mathrm{c}}\right)=\frac{\mathrm{m}}{100} \times \gamma_{d} \times \mathrm{D}
$$

Under surface and improved surface irrigation systems and different irrigation treatments the number of irrigations, date and irrigation intervals (days) according the cumulative Class A Pan evaporation treatments of maize plants were calculated and presented in Table (3) during 2017 and 2018 seasons.

Table (2). Soil moisture constants and soil available water depth ( $\mathrm{mm})$ of the effective root zone of the studied soil.

\begin{tabular}{|c|c|c|c|c|c|c|}
\hline $\begin{array}{c}\text { Depth } \\
\text { (cm) }\end{array}$ & $\begin{array}{c}\text { Field } \\
\text { capacity } \\
(\%)\end{array}$ & $\begin{array}{c}\text { Wilting } \\
\text { point } \\
(\%)\end{array}$ & $\begin{array}{c}\text { Available } \\
\text { water } \\
(\%)\end{array}$ & $\begin{array}{c}\text { Bulk } \\
\text { density } \\
\left(\mathrm{g} \mathrm{cm}^{-3}\right)\end{array}$ & $\begin{array}{c}\text { Available } \\
\text { water } \\
\text { (cm) }\end{array}$ & $\begin{array}{c}\text { Available } \\
\text { water } \\
(\mathbf{m m})\end{array}$ \\
\hline \multicolumn{7}{|c|}{ The first season $(2017)$} \\
\hline $0-20$ & 35.40 & 21.12 & 14.28 & 1.20 & 3.427 & 34.27 \\
\hline $20-40$ & 32.21 & 21.30 & 10.91 & 1.22 & 2.662 & 26.62 \\
\hline $40-60$ & 30.83 & 21.60 & 9.23 & 1.28 & 2.362 & 23.62 \\
\hline \multicolumn{5}{|c|}{ The total soil available water $(0-60 \mathrm{~cm}$ depth $)$} & 8.451 & 84.51 \\
\hline \multicolumn{7}{|c|}{ The second season (2018) } \\
\hline $0-20$ & 35.25 & 21.10 & 14.15 & 1.20 & 3.396 & 33.96 \\
\hline $20-40$ & 32.40 & 21.28 & 11.12 & 1.23 & 2.735 & 27.35 \\
\hline $40-60$ & 30.66 & 21.57 & 9.09 & 1.29 & 2.345 & 23.45 \\
\hline \multicolumn{5}{|c|}{ The total soil available water $(0-60 \mathrm{~cm}$ depth $)$} & 8.476 & 84.76 \\
\hline
\end{tabular}

Where: $\mathrm{m}$ is the soil moisture after and before irrigation treatments.

$\mathrm{D}$ is the depth, $\mathrm{cm}$, and $\gamma_{d}$ is the dry bulk density, $\mathrm{Mg} \mathrm{m}^{-3}$

The water productivity was expressed as $\mathrm{kg}$ maize grains $\mathrm{m}^{-3}$ of water consumed. It has been used to evaluate the effects of different irrigation treatments in producing the maximum yield per water unit consumed by the crop plants (Jensen et al., 1990). The values of water productivity for maize plants were calculated as follows:

$$
\text { Water productivity }=\frac{\text { Grains yield of maize crop }\left(\mathrm{kg} \mathrm{fed} \mathrm{f}^{-1}\right)}{\text { Seasonal crop consumptive use }\left(\mathrm{m}^{3} \mathrm{fed}^{-1}\right)}
$$

The collected data were statistically analyzed using the procedures outlined by Snedecor and Cochran (1980). 
Table (3). Number of irrigation, dates and irrigation intervals (days) according the cumulative Class A Pan evaporation treatments of corn of the two seasons 2017 and 2018.

\begin{tabular}{|c|c|c|c|c|c|c|}
\hline \multirow{2}{*}{$\begin{array}{c}\text { No. of } \\
\text { irrigations }\end{array}$} & \multicolumn{6}{|c|}{ Irrigation treatments (C.P.E.) } \\
\cline { 2 - 7 } & \multicolumn{2}{|c|}{$\mathbf{I}_{\mathbf{1}}$} & \multicolumn{2}{|c|}{$\mathbf{I}_{\mathbf{2}}$} & \multicolumn{2}{c|}{$\mathbf{I}_{\mathbf{3}}$} \\
\cline { 2 - 7 } & Date & $\begin{array}{c}\text { Interval } \\
\text { day }\end{array}$ & date & $\begin{array}{c}\text { Interval } \\
\text { day }\end{array}$ & date & $\begin{array}{c}\text { Interval } \\
\text { day }\end{array}$ \\
\hline planting & August $6^{\text {th }}$ & - & August $6^{\text {th }}$ & - & August $6^{\text {th }}$ & - \\
\hline $1^{\text {st }}$ & $20-8-2017$ & 14 & $24-8-2017$ & 18 & $1-9-2017$ & 25 \\
\hline $2^{\text {nd }}$ & $4-9-2017$ & 15 & $12-9-2017$ & 19 & $28-9-2017$ & 27 \\
\hline $3^{\text {rd }}$ & $20-9-2017$ & 16 & $3-10-2017$ & 21 & $26-10-2017$ & 28 \\
\hline $4^{\text {th }}$ & $8-10-2017$ & 18 & $25-10-2017$ & 22 & $24-11-2017$ & 29 \\
\hline $5^{\text {th }}$ & $28-10-2017$ & 20 & $17-11-2017$ & 23 & --- & -- \\
\hline $6^{\text {th }}$ & $20-11-2017$ & 23 & --- & --- & --- & --- \\
\hline Harvesting & $5-12-2017$ & -- & $5-12-2017$ & -- & $5-12-2017$ & -- \\
\hline
\end{tabular}

\section{Results and discussions}

1. Effect of irrigation systems, irrigation treatments and soil plastic mulching on growth parameters of maize plants

Data in Table (4) show that the highest values of plant height, cobs number per plant and cob weight of maize plants are $253.56 \mathrm{~cm}, 1.78$ and $345.56 \mathrm{gm}$ and had been coincided with $\mathrm{S}_{2}, \mathrm{I}_{2}, \mathrm{M}_{2}$ treatment. Irrigation treatments had a clear effect on all growth parameters which significantly decreased at irrigation treatment $\mathrm{I}_{3}$.

Data in Table (4) show that the improved surface and drip irrigation systems when compared with surface irrigation system lead to significant increase in the mean values of the plant height by 5.35 and $4.84 \%$ for $\mathrm{M}_{0}, 5.72$ and $5.43 \%$ for $\mathrm{M}_{1}$ and 5.72 and $4.81 \%$ for $\mathrm{M}_{2}$ treatment, respectively. The improved surface and drip irrigation systems when compared with surface irrigation system lead to significant increase in the mean values of cobs number per plant by 3.55 and $2.84 \%$ for $\mathrm{M}_{0}$, 7.38 and $2.68 \%$ for $\mathrm{M}_{1}$ and 10.60 and $1.99 \%$ for $\mathrm{M}_{2}$ treatments, respectively. Also, the improved surface and drip irrigation systems when compared with surface irrigation system lead to significant increase in the mean values of cob weight by 3.05 and $0.00 \%$ for $\mathrm{M}_{0}, 3.14$ and $2.67 \%$ for $\mathrm{M}_{1}$ and 7.19 and $3.37 \%$ for $\mathrm{M}_{2}$ treatments, respectively. These results are a good in agreement with those obtained by Payero et al. (2009).

Results in Table (4) indicated also that under improved surface irrigation system, soil black plastic mulching lead to significant increases in the mean values of the maize plant height, stem diameter, cobs number per plant and cob weight values by $7.41,2.46,12.57$ and 5.43 with without mulches and $2.61 \%, 1.05 \%$, $4.19 \%$ and $4.23 \%$ with white mulches, respectively. These results are in agreement with those obtained by Irmak and Rudnick (2014).

Fayoum J. Agric. Res. \& Dev., Vol. 34, No.1, January, 2020 
RATIONALIZE MAIZE IRRIGATION WATER USING MODERN 54

2. Effect of irrigation systems, irrigation treatments and soil plastic mulching on yield and yield components of maize plants.

Data in Table (5) indicated that the variations of both crop parameters were the highest values of number of rows per cob, weight of 100 grain (gm) and grains yield of maize $\left(\mathrm{t} \mathrm{ha}^{-1}\right)$ were 15.07, 24.6 $\mathrm{gm}$ and $9.150 \mathrm{t} \mathrm{ha}^{-1}$, respectively. These values were recorded coincided with $\mathrm{S}_{2} \mathrm{I}_{2} \mathrm{M}_{2}$ treatment. Also, the highest value of forage weight $\left(\mathrm{t} \mathrm{ha}^{-1}\right)$ is $36.6 \mathrm{tha}^{-1}$ and had been recorded coincided with $\mathrm{S}_{1} \mathrm{I}_{1} \mathrm{M}_{2}$ treatment.

However, Table (5) show that under without mulching treatment, improved surface and drip irrigation systems lead to significant increase in the mean values of the number of rows per cob, weight of 100 grains and grain yield by 5.79 and $2.62 \%$, 5.57 and $3.35 \%$ and 12.72 and $4.92 \%$ compared with surface irrigation system, respectively. Also, under white plastic mulching treatment, improved surface and drip irrigation systems when compared with improved surface and drip irrigation systems lead to significant increase in the mean values of the number of rows per cob, weight of 100 grain and grains yield by 6.11 and $3.02 \%, 4.52$ and $3.47 \%$ and 13.70 and $6.01 \%$, respectively. In addition, under black plastic mulching treatment, improved surface and drip irrigation systems when compared with improved surface and drip irrigation systems lead to significant increase in the mean values of the number of rows per cob, weight of 100 grains and grains yield by 5.85 and $3.38 \%$, 3.55 and $3.03 \%$ and 12.09 and $4.16 \%$, respectively. On the other hand, surface irrigation system when compared with improved surface and drip irrigation systems lead to significant increases in the mean values of the forage weight by 1.72 and $4.23 \%, 1.79$ and $3.30 \%$ and 2.73 and $4.06 \%$ for $\mathrm{M}_{0}, \mathrm{M}_{1}$ and $\mathrm{M}_{2}$ treatments, respectively.

Fayoum J. Agric. Res. \& Dev., Vol. 34, No.1, January, 2020 
Table (4). Some plant growth parameters of maize plants as influenced by irrigation treatments and soil plastic mulching under different irrigation systems (as mean values of two seasons 2017 and 2018)*.

\begin{tabular}{|c|c|c|c|c|c|c|c|c|c|c|c|c|c|c|}
\hline \multirow{2}{*}{ 苞 } & \multirow{2}{*}{$\begin{array}{c}\text { No of } \\
\text { irrig. } \\
\text { or } \\
\text { work. } \\
\text { hr. }\end{array}$} & \multirow{2}{*}{ 苞 } & \multicolumn{4}{|c|}{ Without mulching } & \multicolumn{4}{|c|}{ White plastic mulching } & \multicolumn{4}{|c|}{ Black plastic mulching } \\
\hline & & & $\begin{array}{c}\text { Plant } \\
\text { height } \\
(\mathrm{cm})\end{array}$ & \begin{tabular}{|c|} 
Stem \\
diameter \\
$(\mathrm{cm})$
\end{tabular} & $\begin{array}{c}\text { Cobs } \\
\text { No. per } \\
\text { plant }\end{array}$ & \begin{tabular}{|c|} 
Cob \\
weight \\
(gm)
\end{tabular} & $\begin{array}{c}\text { Plant } \\
\text { height } \\
(\mathrm{cm})\end{array}$ & \begin{tabular}{|c} 
Stem \\
diamete \\
$\mathbf{r}(\mathbf{c m})$
\end{tabular} & $\begin{array}{c}\text { Cobs } \\
\text { No. per } \\
\text { plant }\end{array}$ & \begin{tabular}{|c|} 
Cob \\
weight \\
$(\mathrm{gm})$
\end{tabular} & $\begin{array}{c}\text { Plant } \\
\text { height } \\
(\mathrm{cm})\end{array}$ & \begin{tabular}{|c|} 
Stem \\
diamete \\
r $(\mathrm{cm})$
\end{tabular} & $\begin{array}{c}\text { Cobs } \\
\text { No. per } \\
\text { plant }\end{array}$ & \begin{tabular}{|c|} 
Cob \\
weight \\
$(\mathrm{gm})$
\end{tabular} \\
\hline \multirow{4}{*}{ 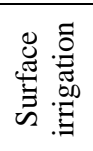 } & 7 & $\mathrm{I}_{1}$ & 214.56 & 2.72 & 1.33 & 291.11 & 220.67 & 2.73 & 1.44 & 305.56 & 225.33 & 2.75 & 1.46 & 306.67 \\
\hline & 6 & $\mathrm{I}_{2}$ & 226.00 & 2.86 & 1.56 & 325.56 & 244.56 & 2.92 & .68 & 318.89 & 250.11 & 93 & .72 & 0.44 \\
\hline & 5 & $\mathrm{I}_{3}$ & 184.11 & 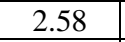 & 133 & 276.67 & 189.56 & 2.60 & 1.34 & 278.89 & 196.89 & 63 & 1.35 & 280.44 \\
\hline & & Mean & 208.22 & 2.72 & 1.41 & 297.78 & 218.26 & 2.75 & 1.49 & 301.11 & 224.11 & 2.77 & 1.51 & 302.52 \\
\hline \multirow{4}{*}{ 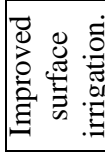 } & 7 & $\mathrm{I}_{1}$ & 227.44 & 2.77 & 1. & 310.33 & 241.89 & 2.79 & 1.67 & 311.67 & 251.33 & 2.83 & .67 & 340.56 \\
\hline & 6 & $\mathrm{I}_{2}$ & 234.89 & 2 & & 327.44 & 247.11 & 2.5 & 1.69 & 336.67 & 253 & 2.92 & 8 & 5.56 \\
\hline & 5 & $\mathrm{I}_{3}$ & 195.78 & 0 & 1.35 & 282.78 & 203.22 & 2.76 & 1.43 & 283.33 & 205.89 & 2.80 & .56 & 286.67 \\
\hline & & Mean & 219.37 & 2.78 & 1.46 & 306.85 & 230.74 & 2.82 & 1.60 & 310.56 & 236.93 & 2.85 & 1.67 & 324.26 \\
\hline \multirow{4}{*}{ :올. } & 31.33 & $\mathrm{I}_{1}$ & 224.67 & 2.78 & 1.44 & 293.89 & 227.11 & 2.80 & 1.56 & 311.22 & 229.11 & 2.81 & 1.57 & 313.89 \\
\hline & 25.06 & $\mathrm{I}_{2}$ & 233.89 & 2. & 1.5 & 311.67 & 240.44 & 2.84 & 1.67 & 328.89 & 251.00 & 2.89 & 1.69 & 330.33 \\
\hline & 18.80 & $\mathrm{I}_{3}$ & 196.33 & 2.70 & 1.34 & 283.89 & 222.78 & 2.74 & 1.35 & 287.33 & 224.56 & 2.76 & 1.36 & 293.89 \\
\hline & & Mean & 218.30 & 2.76 & 1.45 & 296.48 & 230.11 & 2.79 & 1.53 & 309.15 & 234.89 & 2.82 & 1.54 & 312.70 \\
\hline \multicolumn{3}{|c|}{ LSD at $5 \%$} & $S$ & & I & & $\mathrm{M}$ & & $\mathrm{I} \times \mathrm{S}$ & & $\mathrm{M} \times \mathrm{S}$ & $\vec{M} \times I$ & $\overline{\mathrm{M}}$ & $\times \mathrm{I} \times \mathrm{S}$ \\
\hline \multicolumn{3}{|c|}{ Plant height $(\mathrm{cm})$} & 1.026 & & 0.849 & & 0.617 & & 1.410 & & 1.190 & 1. & & 007 \\
\hline \multicolumn{3}{|c|}{ Stem diameter $(\mathrm{cm})$} & 0.018 & & 0.023 & & 0.012 & & 0.0 & & 0.022 & 0. & & 144 \\
\hline \multicolumn{3}{|c|}{ Cobs No. per plant } & 0.032 & & 0.027 & & 0.016 & & 0.044 & & 0.034 & 0.0 & & .057 \\
\hline \multicolumn{3}{|c|}{ Cob weight (gm) } & 17.47 & & 13.33 & & 6.12 & & 22.77 & & NS & 15.38 & & NS \\
\hline
\end{tabular}

Where: *Each value in this table is an average of 3 replicate, $S$ is irrigation system, $M$ is mulching and $I$ is irrigation treatment $\left(I_{1}, I_{2}\right.$ and $I_{3}$ are $100 \%, 80 \%$ and $60 \%$ of crop evapotranspiration, respectively). 
RATIONALIZE MAIZE IRRIGATION WATER USING MODERN.

Table (5). Yield and yield component of maize plants as influenced by irrigation treatments and soil plastic mulching under different irrigation systems (as mean values of two seasons 2017 and 2018)*.

\begin{tabular}{|c|c|c|c|c|c|c|c|c|c|c|c|c|c|c|}
\hline \multirow[b]{2}{*}{ 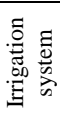 } & \multirow[b]{2}{*}{$\begin{array}{c}\text { No of } \\
\text { irrig. or } \\
\text { work. hr. }\end{array}$} & \multirow[b]{2}{*}{$\begin{array}{l}\text { Irrig. } \\
\text { treat. }\end{array}$} & \multicolumn{4}{|c|}{ Without mulch } & \multicolumn{4}{|c|}{ White plastic mulching } & \multicolumn{4}{|c|}{ Black plastic mulching } \\
\hline & & & $\begin{array}{c}\text { No. } \\
\text { of rows } \\
\text { per cob }\end{array}$ & $\begin{array}{c}\text { Weight of } \\
100 \text { grains } \\
(\mathrm{gm})\end{array}$ & $\begin{array}{l}\text { Forage } \\
\text { weight } \\
\left(\mathrm{t} \mathrm{ha}^{-1}\right)\end{array}$ & $\begin{array}{c}\text { Grains } \\
\text { yield } \\
\left(\mathrm{t} \mathrm{ha}^{-1}\right)\end{array}$ & $\begin{array}{l}\text { No. of } \\
\text { rows per } \\
\text { cob }\end{array}$ & $\begin{array}{c}\text { Weight of } \\
100 \text { grains } \\
(\mathrm{gm})\end{array}$ & $\begin{array}{l}\text { Forage } \\
\text { weight } \\
\left(\mathrm{t} \mathrm{ha}^{-1}\right)\end{array}$ & $\begin{array}{c}\text { Grains } \\
\text { yield } \\
\left(\mathrm{t} \mathrm{ha}^{-1}\right)\end{array}$ & $\begin{array}{l}\text { No. of } \\
\text { rows per } \\
\text { cob }\end{array}$ & $\begin{array}{c}\text { Weight of } \\
100 \text { grains } \\
\text { (gm) }\end{array}$ & $\begin{array}{l}\text { Forage } \\
\text { weight } \\
\left(\mathrm{t} \mathrm{ha}^{-1}\right)\end{array}$ & $\begin{array}{l}\text { Grains } \\
\text { yield } \\
\left(\mathrm{t} \mathrm{ha}^{-1}\right)\end{array}$ \\
\hline \multirow{4}{*}{ 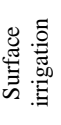 } & 7 & $\overline{I_{1}}$ & 13.00 & 20.08 & 34.8 & 6.891 & 13.41 & 20.99 & 35.5 & $\begin{array}{l}7.038 \\
\end{array}$ & 13.44 & 21.23 & 36.6 & 7.353 \\
\hline & 6 & $\mathrm{I}_{2}$ & 13.56 & 21.49 & 34.5 & 8.089 & 13.78 & 22.37 & 34.9 & 8.219 & 13.87 & 22.86 & 35.1 & 8.330 \\
\hline & 5 & $\mathrm{I}_{3}$ & 12.33 & 19.33 & 22.9 & 6.487 & 12.56 & 19.75 & 26.8 & 6.605 & 12.67 & 20.16 & 27.2 & 6.842 \\
\hline & & Mean & 12.96 & 20.30 & 30.73 & 7.156 & 13.25 & 21.04 & 32.40 & 7.287 & 13.33 & 21.42 & 32.97 & 7.508 \\
\hline \multirow{4}{*}{ 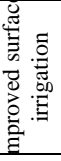 } & 7 & $\mathrm{I}_{1}$ & 13.36 & 20.92 & 33.8 & 8.464 & 13.67 & 21.42 & 34.6 & 8.758 & 13.70 & 21.81 & 35.1 & 8.867 \\
\hline & 6 & $\mathrm{I}_{2}$ & 14.67 & 23.36 & 34.0 & 8.816 & 15.00 & 24.03 & 34.2 & 9.004 & 15.07 & 24.06 & 34.3 & 9.150 \\
\hline & 5 & $\mathrm{I}_{3}$ & 13.11 & 20.00 & 22.8 & 6.920 & 13.50 & 20.51 & 26.7 & 7.094 & 13.56 & 20.67 & 26.8 & 7.232 \\
\hline & & Mean & 13.71 & 21.43 & 30.20 & 8.066 & 14.06 & 21 & 31.83 & 8.285 & 14.11 & 8 & 32.07 & 8.416 \\
\hline \multirow{4}{*}{ 壳. } & 31.33 & $I_{1}$ & 13.33 & 20.26 & 32.9 & 7.338 & 13.52 & 21.14 & 34.3 & 7.554 & 13.67 & 21.65 & 34.9 & 7.645 \\
\hline & 25.06 & $\mathrm{I}_{2}$ & 13.67 & 22.51 & 33.6 & 8.153 & 14.40 & 23.38 & 33.9 & 8.354 & 14.56 & 23.73 & 34.1 & 8.464 \\
\hline & 18.80 & $I_{3}$ & 12.89 & 20.18 & 21.8 & 7.034 & 13.03 & 20.79 & 25.8 & 7.266 & 13.11 & 20.84 & 25.9 & 7.350 \\
\hline & & Mean & 13.30 & 20.98 & 29.43 & 7.508 & 13.65 & 21.77 & $\mathbf{3 1 . 3 3}$ & 7.725 & 13.78 & 22.07 & 31.63 & 7.820 \\
\hline
\end{tabular}

Where: *Each value in this table is an average of 3 replicate, $S$ is irrigation system, $M$ is mulching and $I$ is irrigation treatment $\left(I_{1}, I_{2}\right.$ and $I_{3}$ are $100 \%, 80 \%$ and $60 \%$ of crop evapotranspiration, respectively).

Results in Table (5) indicated that under improved surface irrigation system, soil black plastic mulching lead to significant increase in the mean values of the maize number of rows per cob, weight of 100 grains, forage weight and grains yield values by 2.83 and $0.35 \%, 3.38$ and $0.86 \%, 5.83$ and $0.75 \%$ and 4.16 and $1.56 \%$ compared with the without mulching and white plastic mulching, respectively. However, under drip irrigation system, soil black plastic mulching lead to significant increase in the mean values of the maize number of rows per cob, weight of 100 grains, forage weight and grains yield values by 3.48 and $0.94 \%, 4.94$ and $1.36 \%$, 6.96 and $0.95 \%$ and 3.99 and $1.22 \%$ compared with the without mulching and white plastic mulching, respectively. However, soil plastic mulching influence on maize grains yield more than deficit irrigation treatments. This results are in agreement with those obtained by Wang et al. (2016) who found that in semi-arid areas of China, plastic-film mulched ridge-furrow cropping has been extensively used for maize production.

3. Effect of irrigation systems, irrigation treatments and soil plastic mulching on water consumptive use $\left(\mathrm{m}^{3}\right.$ fed. $\left.{ }^{-1}\right)$ of maize plants.

Results in Table (6) showed that the highest values of water consumptive use of maize plants were 2975.25 and $2915.35 \mathrm{~m}^{3} \mathrm{fed}^{-1}$ at the $1^{\text {st }}$ and $2^{\text {nd }}$ seasons, respectively, and were which coincided with surface irrigation system, irrigation treatment $I_{1}(100 \%$ of ETc) and without soil mulching treatments. On the other hand, the lowest values of water consumptive use of maize plants were 1595.63 and $1569.44 \mathrm{~m}^{3} \mathrm{fed}^{-1}$ at the $1^{\text {st }}$ and $2^{\text {nd }}$ seasons respectively, which were coupled drip irrigation system, irrigation treatment $I_{3}(60 \%$ of ETc) and soil black plastic mulching. These results reflect the high values of maize plants growth parameter which were obtained at irrigation treatments $\mathrm{I}_{1}\left(100 \%\right.$ of ETc) and $\mathrm{I}_{2}(80 \%$ of ETc). These results are in a good agreement with those obtained by Basal et al. (2009)

Fayoum J. Agric. Res. \& Dev., Vol. 34, No.1, January, 2020 
Tolba S. Abdel-Aal",ET,AL.,

who found that using drip irrigation is able to reduce the irrigation water and increase the yield of different crops compared to conventional methods.

The mean values of water consumptive use of maize plants at soil black plastic mulching significantly decreased compared with the without mulching and white plastic mulching treatments under the different used irrigation systems.

The results in Table (6) showed that under drip irrigation system, the mean values of water consumptive use of maize plants significantly decreased by 31.40 and $12.66 \%$ at the $1^{\text {st }}$ season and by 31.11 and $11.54 \%$ at the $2^{\text {nd }}$ season compared with surface and improved surface irrigation systems, respectively. However, the mean values of water consumptive use of maize plants at irrigation treatment $\mathrm{I}_{1}$ $(100 \%$ of ETc) were significantly increased when compared with irrigation treatments $I_{2}\left(80 \%\right.$ of ETc) and $I_{3}(60 \%$ of ETc) under the different used irrigation systems.

Table (6). Effect of irrigation treatments and soil plastic mulching on water consumptive use of maize plants $\left(\mathrm{m}^{3}\right.$ fed $\left.^{-1}\right)$ under different irrigation systems (as mean values of two seasons 2017 and 2018)*.

\begin{tabular}{|c|c|c|c|c|c|c|c|c|c|c|}
\hline \multirow{2}{*}{ 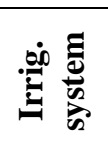 } & \multirow{2}{*}{$\begin{array}{c}\text { No of } \\
\text { irrig. or } \\
\text { work. hr. }\end{array}$} & \multirow{2}{*}{ 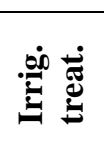 } & \multicolumn{4}{|c|}{$1^{\text {st }}$ season $(2017)$} & \multicolumn{4}{|c|}{$2^{\text {nd }}$ season $(2018)$} \\
\hline & & & $\mathbf{M}_{0}$ & $\mathbf{M}_{1}$ & $\mathbf{M}_{2}$ & mean & $\mathbf{M}_{0}$ & $\mathbf{M}_{1}$ & $\mathbf{M}_{2}$ & mean \\
\hline \multirow{4}{*}{ 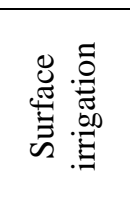 } & 7 & $\mathrm{I}_{1}^{*}$ & 2975.25 & 2910.35 & 2870.24 & 2918.61 & 2915.35 & 2860.53 & 2810.45 & 2862.11 \\
\hline & 6 & $\mathrm{I}_{2}$ & 2560.54 & 2454.65 & 2396.75 & 2470.65 & 2492.64 & 2396.74 & 2324.83 & 2404.74 \\
\hline & 5 & $\mathrm{I}_{3}$ & 2145.26 & 2058.85 & 1982.45 & 2062.19 & 2139.96 & 2052.35 & 1968.43 & 2053.58 \\
\hline & & mean & 2560.35 & 2474.62 & 2416.48 & 2483.82 & 2515.98 & 2436.54 & 2367.90 & 2440.14 \\
\hline \multirow{4}{*}{ 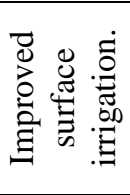 } & 7 & $\mathrm{I}_{1}$ & 2664.56 & 2576.54 & 2490.45 & 2577.18 & 2614.42 & 2535.47 & 2400.72 & 2516.87 \\
\hline & 6 & $\mathrm{I}_{2}$ & 2131.20 & 2063.45 & 1982.63 & 2059.09 & 2115.20 & 2024.23 & 1940.43 & 2026.62 \\
\hline & 5 & $\mathrm{I}_{3}$ & 1798.40 & 1755.60 & 1704.24 & 1752.75 & 1736.40 & 1665.43 & 1650.66 & 1684.16 \\
\hline & & mean & 2198.05 & 2131.86 & \begin{tabular}{|l|}
2059.11 \\
\end{tabular} & 2129.67 & 2155.34 & 2075.04 & 1997.27 & \begin{tabular}{|l|}
2075.88 \\
\end{tabular} \\
\hline \multirow{4}{*}{ 离. } & 31.33 & $\mathrm{I}_{1}$ & 2268.24 & 2175.00 & 2050.45 & 2164.56 & 2196.65 & 2124.14 & 1998.47 & 2106.42 \\
\hline & 25.06 & $\mathrm{I}_{2}$ & 1914.59 & 1825.87 & 1754.58 & 1831.68 & 1895.32 & 1805.33 & 1747.52 & 1816.06 \\
\hline & 18.80 & $\mathrm{I}_{3}$ & 1760.94 & 1667.65 & 1595.63 & 1674.74 & 1740.99 & 1672.54 & 1569.44 & 1660.99 \\
\hline & & mean & 1981.26 & 1889.51 & 1800.22 & 1890.33 & 1944.32 & 1867.34 & 1771.81 & 1861.16 \\
\hline \multicolumn{3}{|c|}{ LSD at $5 \%$} & $\mathbf{S}$ & I & $\mathbf{M}$ & $\mathbf{I} \times \mathbf{S}$ & $\mathbf{M} \times \mathbf{S}$ & $\mathbf{M} \times \mathbf{I}$ & $\times \mathbf{I}$ & $\mathbf{I} \times \mathbf{I} \times \mathbf{S}$ \\
\hline \multicolumn{3}{|c|}{$1^{\text {st }}$ season } & 3.44 & 1.63 & 1.54 & 3.62 & 3.59 & 2.64 & 64 & 5.02 \\
\hline \multicolumn{3}{|c|}{$2^{\text {nd }}$ season } & 2.10 & 2.38 & 1.62 & 3.65 & 2.79 & 3.18 & 18 & 5.23 \\
\hline
\end{tabular}

Where: *Each value in this table is an average of 3 replicate, $\mathrm{M}_{0}, \mathrm{M}_{1}$ and $\mathrm{M}_{2}$ are without, white plastic and black plastic mulching, respectively. $\mathrm{I}_{1}, \mathrm{I}_{2}$ and $\mathrm{I}_{3}$ are $100 \%, 80 \%$ and $60 \%$ of crop evapotranspiration, respectively.

Fayoum J. Agric. Res. \& Dev., Vol. 34, No.1, January, 2020 
RATIONALIZE MAIZE IRRIGATION WATER USING MODERN

Also, the mean values of water consumptive use of maize plants at surface irrigation system were significantly increased when compared with improved and drip irrigation systems, under the different irrigation treatments 100, 80 and $60 \%$ of ETc $\left(\mathrm{I}_{1}, \mathrm{I}_{2}\right.$ and $\left.\mathrm{I}_{3}\right)$. The obtained results were in agreement with those obtained by Kadasiddappa and Praveen (2018).

4. Effect of irrigation systems, irrigation treatments and soil plastic mulching on water productivity of maize plants.

Data in Table (7) and Figure (1) indicated that the highest values of water productivity of maize plants are 2.023 and $2.039 \mathrm{~kg} \mathrm{~m}^{-3}$ at the $1^{\text {st }}$ and at $2^{\text {nd }}$ seasons which were coincided with drip irrigation system, irrigation treatment $\mathrm{I}_{2}$ (80\% of ETc) and with soil black plastic mulching. On the other hand, the lowest values of water productivity of maize plants are 0.963 and $1.003 \mathrm{~kg} \mathrm{~m}^{-3}$ at the $1^{\text {st }}$ and $2^{\text {nd }}$ seasons which were coincided with surface irrigation system, irrigation treatment $I_{1}$ $(100 \%$ of ETc) and with the without mulching. These results may reflect the lowest values of maize grains yield which coupled with irrigation treatments $\mathrm{I}_{3}(60 \%$ of ETc) and $I_{1}(100 \%$ of ETc) treatments, while the highest ones were observed with irrigation treatments $I_{2}(80 \%$ of ETc). However, Table (7) showed that, the mean values of water productivity of maize plants at soil black plastic mulching were significantly increased when compared with the without mulching and white plastic mulching treatments under the different used irrigation systems. The obtained results were in agreement with those obtained by Wu et al. (2017).

The results in Table (7) showed that under drip irrigation system, the mean values of water productivity of maize plants significantly increased by 27.27 and $4.08 \%$ at the $1^{\text {st }}$ season and by 26.98 and $3.68 \%$ at the $2^{\text {nd }}$ season compared with surface and improved surface irrigation systems, respectively. Also, the mean values of water productivity of maize plants at irrigation treatment $I_{1}(100 \%$ of ETc) significantly decreased compared with irrigation treatments $I_{2}\left(80 \%\right.$ of ETc) and $I_{3}$ (60\% of ETc) under the different used irrigation systems. The obtained results were in agreement with those obtained by also, Ali and Mohammed (2015) revealed that use of gated pipes system as compared to surface irrigation reduced water application.

Fayoum J. Agric. Res. \& Dev., Vol. 34, No.1, January, 2020 
Tolba S. Abdel-Aal",ET,AL.,

Table (7). Effect of irrigation treatments and soil plastic mulching on water productivity $\left(\mathrm{kg} \mathrm{m}^{-3}\right)$ under different irrigation systems in clayey soils (as mean values of two seasons 2017 and 2018)*.

\begin{tabular}{|c|c|c|c|c|c|c|c|c|c|c|}
\hline \multirow{2}{*}{ 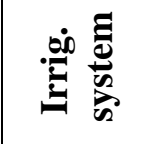 } & \multirow{2}{*}{$\begin{array}{c}\text { No of } \\
\text { irrig. or } \\
\text { work. hr. }\end{array}$} & \multirow{2}{*}{ 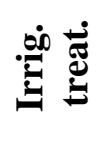 } & \multicolumn{4}{|c|}{$1^{\text {st }}$ season (2017) } & \multicolumn{4}{|c|}{$2^{\text {nd }} \operatorname{season}(2018)$} \\
\hline & & & $\mathbf{M}_{\mathbf{0}}$ & $\mathbf{M}_{1}$ & $\mathbf{M}_{2}$ & mean & $\mathbf{M}_{0}$ & $\mathbf{M}_{1}$ & $\mathbf{M}_{2}$ & mean \\
\hline \multirow{4}{*}{ 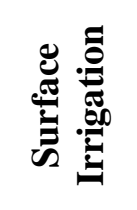 } & 7 & $\mathrm{I}_{1}$ & 0.963 & 1.008 & 1.103 & 1.025 & 1.003 & 1.042 & 1.072 & 1.039 \\
\hline & 6 & $\mathrm{I}_{2}$ & 1.312 & 1.387 & 1.453 & 1.384 & 1.379 & 1.461 & 1.513 & 1.451 \\
\hline & 5 & $\mathrm{I}_{3}$ & 1.244 & 1.322 & 1.443 & 1.336 & 1.300 & 1.378 & 1.468 & 1.382 \\
\hline & & mean & 1.173 & 1.239 & 1.333 & 1.248 & 1.228 & 1.294 & 1.351 & 1.291 \\
\hline \multirow{4}{*}{ 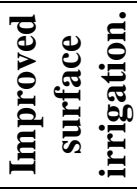 } & 7 & $\mathrm{I}_{1}$ & 1.323 & 1.432 & 1.492 & 1.416 & 1.372 & 1.448 & 1.556 & 1.459 \\
\hline & 6 & $\mathrm{I}_{2}$ & 1.735 & 1.810 & 1.911 & 1.819 & 1.754 & 1.892 & 2.010 & 1.886 \\
\hline & 5 & $\mathrm{I}_{3}$ & 1.613 & 1.715 & 1.782 & 1.703 & 1.678 & 1.771 & 1.842 & 1.764 \\
\hline & & mean & 1.557 & 1.652 & 1.728 & 1.646 & 1.602 & 1.704 & 1.803 & 1.703 \\
\hline \multirow{4}{*}{ 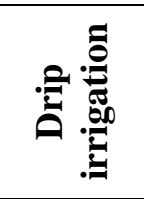 } & 31.33 & $\mathrm{I}_{1}$ & 1.351 & 1.442 & 1.562 & 1.452 & 1.412 & 1.512 & 1.612 & 1.512 \\
\hline & 25.06 & $\mathrm{I}_{2}$ & 1.752 & 1.913 & 2.023 & 1.896 & 1.845 & 1.954 & 2.039 & 1.946 \\
\hline & 18.80 & $\mathrm{I}_{3}$ & 1.654 & 1.814 & \begin{tabular}{|l|}
1.931 \\
\end{tabular} & 1.800 & 1.722 & 1.842 & 1.972 & $\mathbf{1 . 8 4 5}$ \\
\hline & & mean & 1.586 & 1.723 & \begin{tabular}{|l|}
1.839 \\
\end{tabular} & 1.716 & 1.660 & \begin{tabular}{|l|l|}
1.769 \\
\end{tabular} & 1.874 & 1.768 \\
\hline \multicolumn{3}{|c|}{ LSD at $5 \%$} & $\mathbf{S}$ & I & $\mathbf{M}$ & $\mathbf{S} \times \mathbf{I}$ & $\mathbf{S} \times \mathbf{M}$ & $\mathbf{I} \times \mathbf{M}$ & \multicolumn{2}{|c|}{$\mathbf{S} \times \mathbf{I} \times \mathbf{M}$} \\
\hline \multicolumn{3}{|c|}{$1^{\text {st }}$ season } & 0.0026 & 0.0018 & 0.0017 & 0.0032 & 0.0031 & 0.0029 & \multicolumn{2}{|c|}{0.0050} \\
\hline \multicolumn{3}{|c|}{$2^{\text {nd }}$ season } & 0.0013 & 0.0022 & 0.0017 & 0.0032 & 0.0026 & 0.0031 & \multicolumn{2}{|c|}{0.0051} \\
\hline
\end{tabular}

Where: *Each value in this table is an average of 3 replicate, $M_{0}, M_{1}$ and $M_{2}$ are without, white plastic and black plastic mulching, respectively, $I_{1}, I_{2}$ and $I_{3}$ are $100 \%, 80 \%$ and $60 \%$ of crop evapotranspiration, respectively.

The mean values of water productivity of maize plants at surface irrigation system were significantly decreased when compared with improved surface and drip irrigation systems under the different used irrigation treatments $I_{1}(100 \%), I_{2}(80 \%)$ and $\mathrm{I}_{3}(60 \%)$ of ETc. The obtained results were in agreement with those obtained by Li et al. (2017) who found that the Ridge-furrow with plastic film mulching practice increased WUE by $29.2 \%$ and $70.5 \%$, compared to the traditional flat planting and well irrigation planting practices, respectively, for the summer-maize season.

Fayoum J. Agric. Res. \& Dev., Vol. 34, No.1, January, 2020 

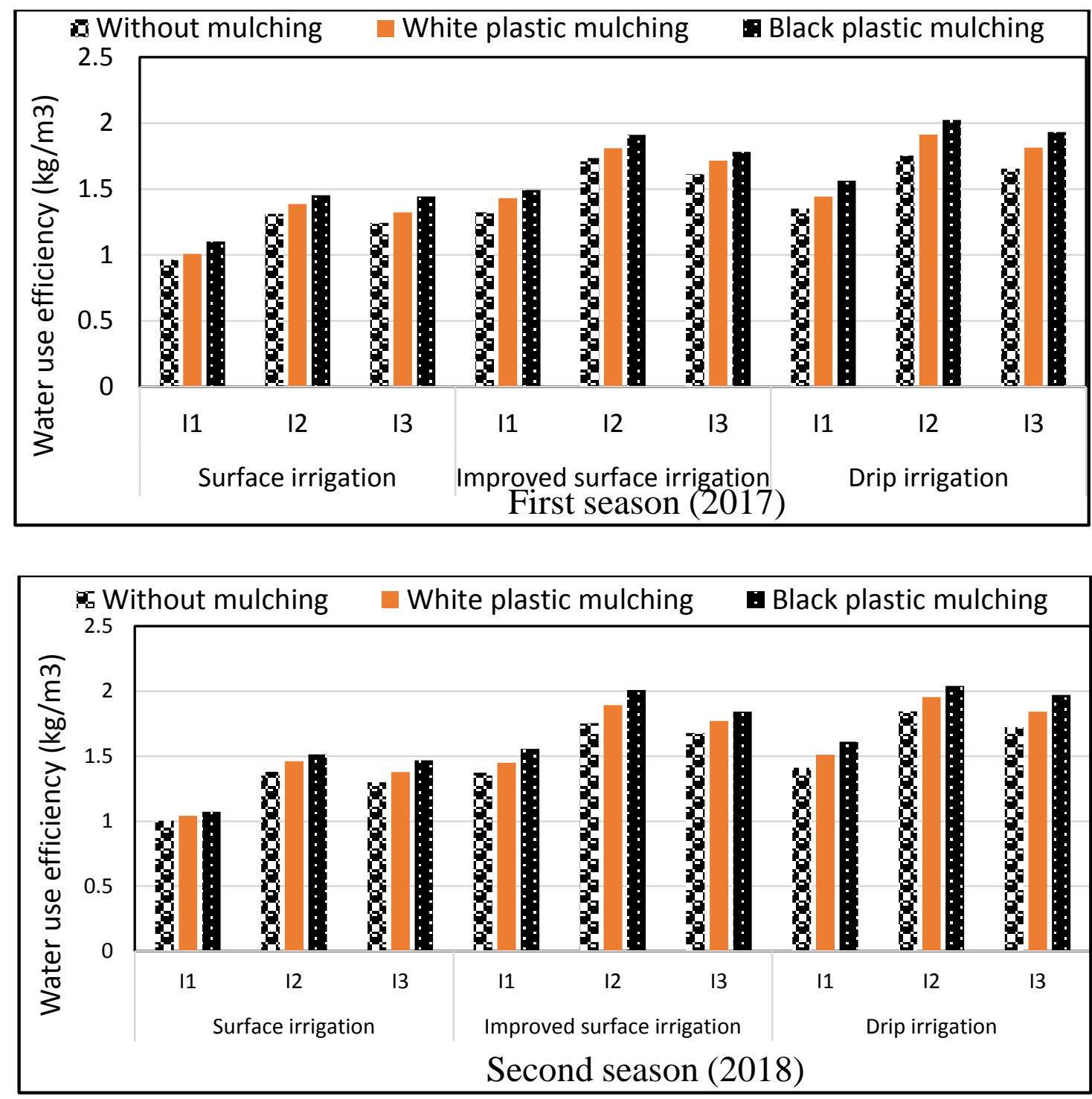

Figure (1). Effect of irrigation treatments and soil plastic mulching on water productivity $\left(\mathrm{kg} / \mathrm{m}^{3}\right)$ under different irrigation systems in seasons (2017 and 2018).

5. Economic income of the maize crop as affected by different irrigation systems, irrigation treatments and soil plastic mulching.

The obtained data in Table (8) indicated that using improved surface irrigation system resulted in the highest value of maize economic income (9522.82 L.E.) compared with surface (8450.65 L.E.) and drip (8548.46 L.E.) irrigation systems. The economic income of maize crop under improved surface and drip irrigation systems increased by 12.69 and $1.16 \%$ compared with surface irrigation system, respectively. On the other hand, under three different irrigation systems, the

Fayoum J. Agric. Res. \& Dev., Vol. 34, No.1, January, 2020 
Tolba S. Abdel-Aal ,ET,AL.,

highest values of maize crop economic income recorded at irrigation treatment $\mathrm{I}_{2}$ $\left(80 \%\right.$ of ETc) compared with irrigation treatments $\mathrm{I}_{1}\left(100 \%\right.$ of ETc) and $\mathrm{I}_{3}(60 \%$ of ETc). The highest values of maize crop economic income under irrigation treatment $\mathrm{I}_{2}(80 \%$ of ETc) application are 10004.65, 10832.38 and 9734.40 L.E. at surface, improved surface and drip irrigation systems, respectively. The obtained results were in agreement with those obtained by Zhang et al. (2017) who showed the optimizing water productivity and economic return of high yield spring maize coincided with drip irrigation and plastic mulching in arid areas of China.

The results in Table (8) showed that, the economic income of maize crop at irrigation treatment $\mathrm{I}_{2}$ (80\% of ETc) were exceeded with 16.84 and $29.76 \%$ for surface irrigation system, 4.80 and $31.47 \%$ for improved surface irrigation system and 15.06 and $21.49 \%$ for drip irrigation system when compared with irrigation treatments $\mathrm{I}_{1}\left(100 \%\right.$ of ETc) and $\mathrm{I}_{3}(60 \%$ of ETc), respectively. These results are fallen in the same line of those stated by Zairi et al. (2003).

Data recorded in Table (8) showed that the values of maize crop economic income were increased at soil without mulching treatments under different irrigation systems and irrigation treatments compared with soil white and black plastic mulching treatments. These results may reflect the costs of soil mulching treatments compared with the soil without mulching treatment. It could be concluded that the improved surface irrigation system, irrigation treatment $I_{2}(80 \%$ of ETc) and black plastic mulching produced the high values of growth parameters, grains yield and yield component of maize plants, as well as, it saved @ 20\% of the applied irrigation water@965 m $\mathrm{ha}^{-1}$ in clayey soils under Fayoum conditions.

Fayoum J. Agric. Res. \& Dev., Vol. 34, No.1, January, 2020 
RATIONALIZE MAIZE IRRIGATION WATER USING MODERN

62

Table (8). Maize crop economic income as influenced by irrigation treatments and soil plastic mulching under different irrigation systems (average values of the two seasons 2017 and 2018).*

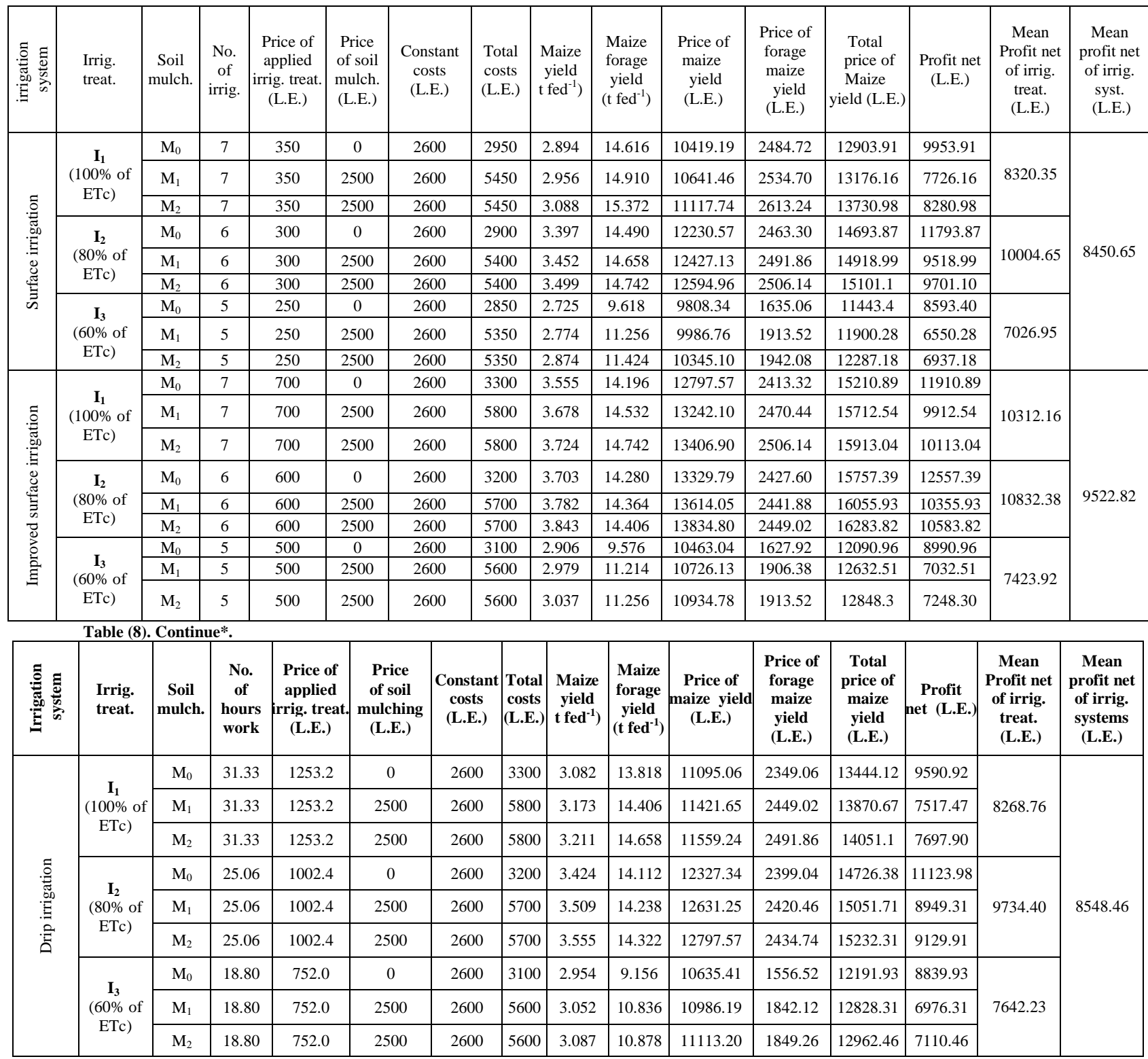

* One irrigation in surface irrigation system $=50$ L.E., one irrigation in improved surface irrigation system $=100$ L.E., one hour irrigation in drip irrigation system $=40$ L.E. one $\mathrm{m}^{2}$ of white or black plastic mulch $=1$ L.E. $\left(M_{0}\right.$ is without mulch, $M_{1}$ is white plastic mulch and $M_{2}$ is black plastic mulch), Constant costs $=2600$ L.E. (700 L.E. plowing and leveling +100 L.E. ridges +250 L.E. planting +800 L.E. chemical fertilizers +350 L.E. hoeing + 400 L.E. harvesting), $1 \mathrm{~kg}$ of maize yield $=3.6 \mathrm{~L} . \mathrm{E}$ and 1 ton of forage maize yield $=170 \mathrm{~L} . \mathrm{E}$. 


\section{REFERENCES}

Abd El-Wahed, M.H. and Ali, E.A. (2013). Effect of irrigation systems, amounts of irrigation water and mulching on corn yield, water use efficiency and net profit. Agric. Water Manage., 120: 64-71.

Abdel-Raheem, H.A. and Elwan, A.M. (2016). Gated Pipes Irrigation System for Optimum Water Productivity of Sugar cane in Egypt J. of Amer. Sci.; 12(7): 215-225.

Abo Soliman, M.S.M.; Shams El-Din, H.A.; Saied, M.M.; El-Barbary, S.M.; Ghazy, M.A. and El-Shahawy, M.I. (2008). Impact of field irrigation management on some irrigation efficiencies and production of wheat and soybean crope. Zagazig J. Agric. Res., 35(2): 363-381.

Aguilar, M., Borjas, F. and Espinosa, M. (2007). Agronomic response of maize to limited levels of water under furrow irrigation in southern Spain. Spanish J. of Agric. Res., 5(4): 587-592.

Ahmed, E.A.E.; El-Begawy, M.E.M.K. and Moussa, H.M. (2013). Economic analysis of the risk in the Egyptian crops structure focusing on the water resources. J. of Applied Sci. Res.; 9(1): 719-725.

Ali, O.A.M. and Mohammed, A.S.H. (2015). Performance evaluation of gated pipes technique for improving surface irrigation efficiency in maize hybrids. Agric. Sci., 6(5): 550-570.

Allen, R.G., Pereira, L.S., Raes, D. and Smith, M. (1998). Crop evapotranspirationGuidelines for computing crop water requirements. FAO 56. FAO, Rome. 300:D05109.

Basal, H., Dagdelen, N., Unay. A. and Yilmaz, E. (2009). "Effects of deficit drip irrigation on Cotton yield and fiber quality". Agronomy and Crop Science, 159: 19-29.

Doorenbos, J. and Pruitt, W.O. (1992). Crop water requirements. FAO Irrigation and Drainage. Paper, No. 24, FAO, Rome. 144.

FAO (Food and Agriculture Organization of the United Nations). (2016). AQUASTAT. Thematic discussion. Available online at http://www.fao.org/nr/water/aquastat/wateruse/index.stm\#discussion (verified on November 16, 2018).

Irmak, S. and Rudnick, D.R. (2014). Corn irrigation management under water-limiting conditions. Univ. of Nebraska-Lincoln Extension Circular EC2007.

Israelsen, O.W. and Hansen, V.C. (1962) (edt). "Irrigation Principles and Practices. " John Wiley \& Sons Inco., New York, U.S.A.

Jensen, M.E., Burman, R.D. and Allen, R.G. (Eds.) (1990). Evapotranspiration and irrigation water requirements. Manuals and Reports on Engineering Practice Number 70. Amer. Soc. Civil Engin., New York, 332 pp.

Jibin, L. and Foroud, N. (2007). Evaluation of a gated pipe basin irrigation method in China. http://www.Geocities.com/ResearchTriangle/Thinktank/2097/gated pipe.htm6/04/22.

Kadasiddappa, M., Praveen R.V., Yella R.K., Uma, D.M and Narender R.S. (2016). Growth, yield and water productivity of drip irrigated maize (Zea mays L.) in peninsular region of India. Abstract paper presented in: International conference on Climate Change, Water, Agriculture and Food Security. Held during 2-3 Nov. 2016 at ICRISAT, India. Pp: 142.

Fayoum J. Agric. Res. \& Dev., Vol. 34, No.1, January, 2020 
RATIONALIZE MAIZE IRRIGATION WATER USING MODERN 64

Kadasiddappa, M.M. and Praveen R.V. (2018). Irrigation scheduling through drip and surface methods- A critical review on growth, yield, nutrient uptake and water use studies of rabi maize. Agric. Reviews, 39(4): 300-306.

Klute, A. (ed.) (1986). Methods of Soil Analysis. Part-I: Physical and Mineralogical Methods. $\left(2^{\text {nd }}\right)$. American Society of Agronomy, Madison, Wisconsin, U.S.A.

Li, C. Wang, C., Wen, X. Qin, X. Liu, Y. Han, J. Li, Y. Liao, Y. and Wu, W. (2017). Ridge-furrow with plastic film mulching practice improves maize productivity and resource use efficiency under the wheat-maize doublecropping system in dry semi-humid areas. Field Crops Res., 203: 201-211.

Memon, M.S., Ali, K., Siyal, A.A., Guo, J., Memon, S.A., Soomro, S.A., Memon, N. and Ji, C. (2018). Effects of plastic sheet on water saving and yield under furrow irrigation method in semi-arid region. Int. J. Agric. and Biol. Eng., 11(1) 174.

Page, A.I.; Miller R.H. and Keeney, D.R. (Eds) (1982). "Methods of Soil Analysis" part 2: Chemical and Microbiological Properties. $2^{\text {nd }}$ ed. Amer. Soc. of Agron., Madison, Wisconsin, U.S.A.

Payero, J.O., Tarkalson, D.D., Irmak, S., Davison, D. and Petersen, J.L. (2009). Effect of timing of a deficit-irrigation allocation on corn evapotranspiration, yield, water use efficiency and dry mass. Agric. Water Manage., 96: 1387-1397.

Ramulu, V., Devi, M.U. and Suresh, K. (2019). Effect of sensor based irrigation scheduling practices under drip and furrow method of irrigation on growth parameters, shelling percentage and test weight of Rabi maize. J. of Pharmacognosy and Phytochemistry. 8(1): 934-937.

Shinde, S.A., Shelke, D.K. and Sawargoankar, G.L. (2009). Effect of irrigation schedules and integrated nutrient management on yield and nutrient uptake of rabi maize (Zea mays L.). International J. of Plant Sci., 4(1): 24-26.

Shukla, A.K.; Pathak, R.K.; Tiwari, R.P. and Nath V. (2001). Influence of irrigation and mulching on plant growth and leaf nutrient status of aonla (Emblica officinalis G.) under sodic soil. J. of Appl. Hort. (Lucknow), 2 (1): 37-38.

Silungwe, F. R., Mahoo, H.F and Kashaigili, J.J. (2010). Evaluation of water productivity for maize under drip irrigation. Second RUFORUM Biennial Meeting. 20-24, September 2010, Entebbe, Uganda. 725-728.

Snedecor, G.W. and Cockran, W.G. (1980). "Statistical Methods" (7m ed.). Iowa State University, Iowa, U.S.A. soil physical conditions: a review. Nut. Cycl. Agroecosyst., 51: 123-137.

Sonbol, H.A; El-Hadid, E.M.; Saied, M.M. and Abou El-Soud, H.M. (2010). Effect of surface and drip irrigation systems on sugar beet yield, irrigation performances and oil salinity at North Delta. J. of Soil Science and Agric. Engine., Mansoura Univ., 1 (4): 407-420.

Wang, H.L., Zhang, X.C., Song, S.Y., Ma, Y.F., Yu, X.F. and Liu, Y. (2011). Effects of whole field-surface plastic mulching and planting in furrow on soil temperature, soil moisture, and corn yield in arid area of Gansu Province. Northwest Chin Chinese J. of Applied Ecology, 22(10): 8-14.

Wang, Y.P., Li, X.G., Zhu, J., Fan, C.Y., Kong, X.J., Turner, N.C., Siddique, K.H.M. and Li, F.M. (2016). Multi-site assessment of the effects of plastic-film mulch on dryland maize productivity in semiarid areas in China. Agric. For. Meteorol., 220: 160-169.

Fayoum J. Agric. Res. \& Dev., Vol. 34, No.1, January, 2020 
Tolba S. Abdel-Aal, ET,AL.,

Wu, D.; Xu, X.; Sokolowski, E. and Mi, G. (2017). Enhancing maize productivity via drip irrigation and drip fertigation on a sandy soil in northeast China. Electronic Intern. Fertilizer Correspondent (e-ifc). (50): 3-10.

Zairi, A., El Amami, H., Slatni, A., Pereira, L.S., Rodrigues, P.N. and Machado, T. (2003). Coping with drought: deficit irrigation strategies for cereals and field horticultural crops in Central Tunisia. In: Rossi, G., Cancelliere, A., Pereira, L.S., Oweis,T., Shatanawi, M., Zairi, A. (Eds.), Tools for Drought Mitigation in Mediterranean Regions. Kluwer, Dordrecht, pp. 181-201.

Zhang, G., Liu C., Xiao, C., Xie, R., Ming, B., Hou, P., Liu, G., Xua, W., Shena, D., Wang, K. and Li, S. (2017). Optimizing water use efficiency and economic return of super high yield spring maize under drip irrigation and plastic mulching in arid areas of China. Field Crops Res., 211: 137-146.

\section{ترشيد مياه الري للذرة الثامية باستخدام نظم الري الحديثة وتغطية سطح التربة بالبلاستيك في

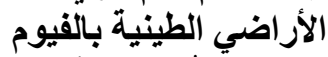

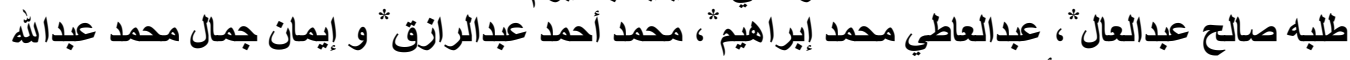

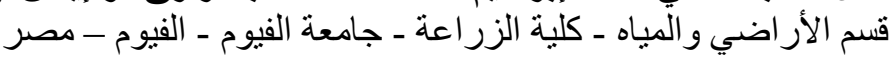

استخدام نظم الري الحديثة يساعد على التغلب على نقص مياه الري و التحكم في استهلاكها، ويؤدي

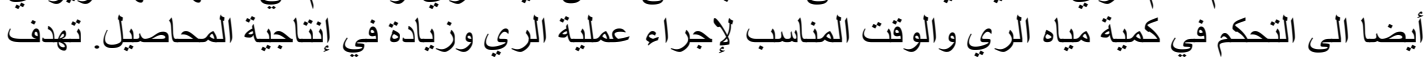
هذه الدراسة الى تقييم نظم الري السطحي والري الري السطحي المطور والري الري بالتئقيط وتغطية سطح التربة

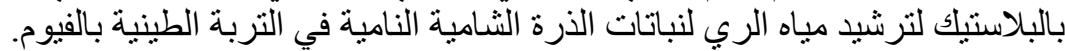

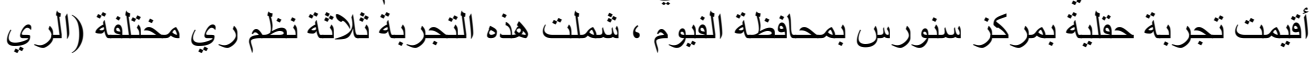

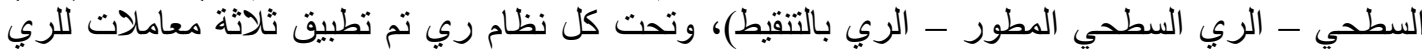

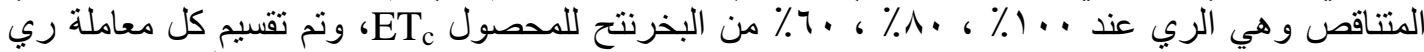

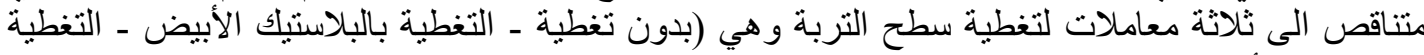

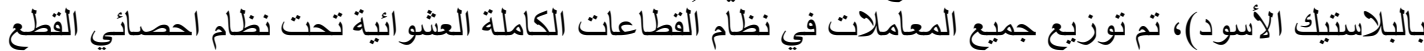

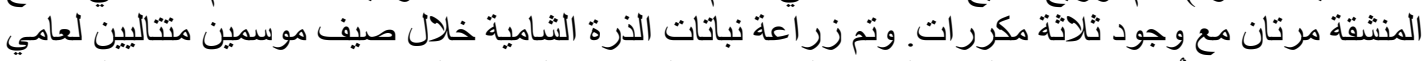

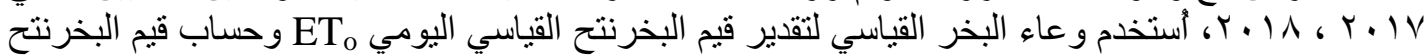

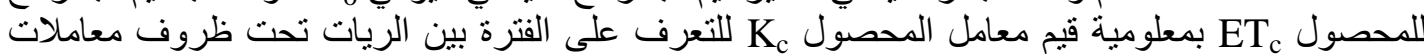

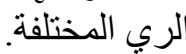

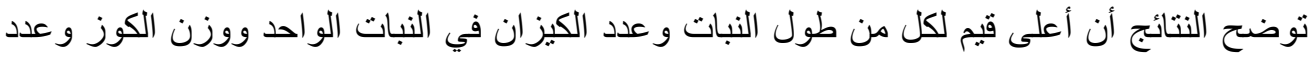

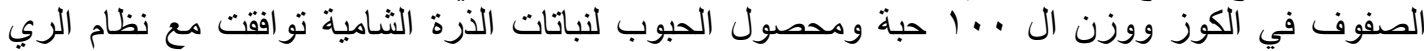

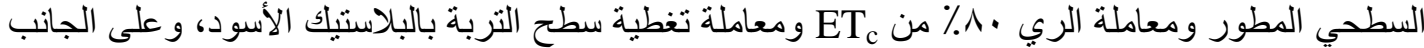

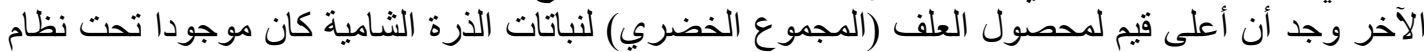

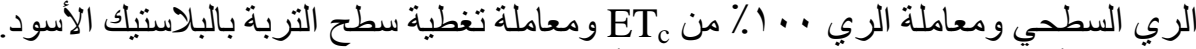

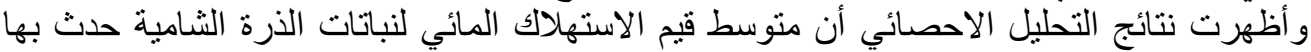

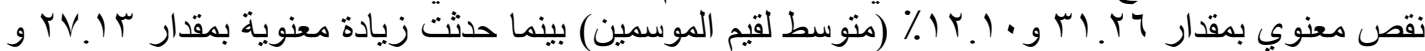

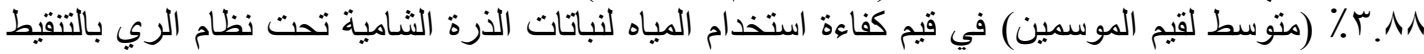

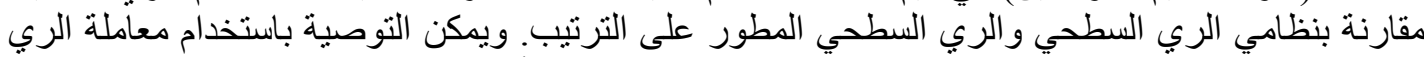

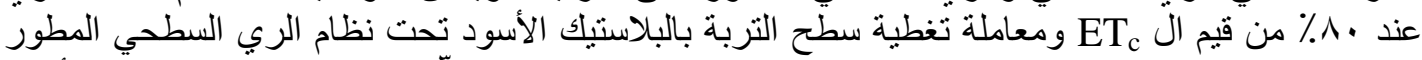

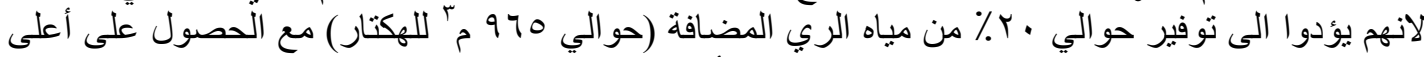

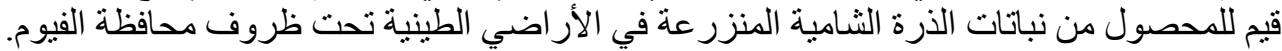
الكلمات الدالة: ترشيد مياه الري، الري السطحي المطور ، الري بالتنقيط، الري المتناقص، تغطية سطح التربة التربة،

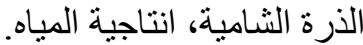

Fayoum J. Agric. Res. \& Dev., Vol. 34, No.1, January, 2020 